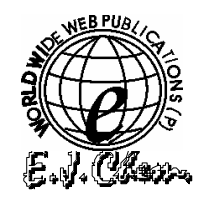

http://www.e-journals.net
CODEN ECJHAO

E-Journal of Chemistry

Vol. 2, No. 4, pp 224 -227, September 2005

\title{
Solvent Free Synthesis of Chalcones and their Antibacterial Activities
}

\author{
RAJENDRA K. SAINI*, AMIT S.CHOUDHARY, \\ YOGESH.C. JOSHI and P. JOSHI ${ }^{\#}$ \\ Department of Chemistry, University of Rajasthan, Jaipur - 302004, India. \\ ${ }^{\#}$ S.S. Jain Subodh P.G. College, Jaipur-302004, Rajasthan.
}

Received 7 July 2005; Accepted 28 August 2005

\begin{abstract}
The solvent free synthesis of six chalcones was carried out by grinding the piperanal and the acetophenone (unsubstituted, 4-methyl, 4-methoxy, 4-bromo, 4-nitro, 3 -chloro) in the presence of solid sodium hydroxide with a mortar and pestle. In general, the chalcones were obtained in high yield and high purity. Minor quantities of Ketol and Michael addition product were easily removed by recrystallization. The result indicates a correlation between the success of the solvent-free synthesis and melting point of the chalcone. Chalcone with relatively high melting points (higher than $80^{\circ} \mathrm{C}$ ) were obtained in high yields. The two chalcones that could not be produced in good yields were having relatively low melting points. They have been screened for their antibacterial activity against Gram positive and Gram negative bacteria.
\end{abstract}

Key words: Solvent free synthesis, Chalcone, Antibacterial activity

\section{Introduction}

Chalcones derivatives constitute an important class of compounds possessing diverse type of biological properties including Antiplasmodial ${ }^{1}$, Antibacterial ${ }^{2}$, Trypanocidal and Leishmanicidal Properties $^{3}$, Antitumour ${ }^{4,5}$, Antiinflammatory ${ }^{6}$, Antiviral activites ${ }^{7}$. Extensive work on synthesis of chalcones has been done by various routes. Condensation of the appropriate acetophenone and piperanal in the presence of sodium hydroxide (solid) via solvent free path $^{8}$ yielded the corresponding 1,3-diarylchalcones. 
The chalcones possess an $\alpha, \beta$-unsaturated grouping in the molecules. The structural assignment of these chalcones was based on elemental analysis, IR and NMR spectral data. The antibacterial activity of these chalcones has been studied by cup-plate method $^{9,10,11}$.

\section{Experimental}

Melting points are uncorrected. The IR spectra were recorded in $\mathrm{KBr}$ disc on a Nicolet Megna-FT-IR 550 spectrometer, ${ }^{1} \mathrm{H}$ NMR were recorded on model DRX 300 at 300.13 in $\mathrm{CDCl}_{3} / \mathrm{DMSO} \mathrm{d}_{6}$ using TMS as internal standard. The purity of the newly synthesized compounds was checked by TLC.

\section{Solvent free synthesis of chalcone}

The solvent free synthesis of chalcones was carried out by grinding the piperanol $(0.05 \mathrm{~mol})$ and acetophenone derivative $(0.05 \mathrm{~mol})$ in presence of solid sodium hydroxide $(0.05 \mathrm{~mol})$ : petroleum ether (1:1) yielded the crystalline product. Purity of the compounds was checked by TLC using $\mathrm{CHCl}_{3}$ as mobile phase.

\section{Spectral studies}

The IR spectra showed a characteristic bands at 1645-1635 (C=O), 1580-1570 $\mathrm{cm}^{-1}(\mathrm{C}=\mathrm{C})$, asymmetrical C-O-C stretching band around $1200-1275 \mathrm{~cm}^{-1}$ and symmetrical stretching at 1020-1075 $\mathrm{cm}^{-1}$. In ${ }^{1} \mathrm{H}$ NMR, a singlet was observed at $\delta$ 5.98-6.01 due to dioxymethylene group. Doublet at 7.82 for $\alpha$-proton and 8.02 for $\beta$-proton in chalcones.

A complicated pattern in the aromatic region at $\delta$ 6.9-8.2 showed the presence of seven aromatic protons. Elemental analysis and ${ }^{1} \mathrm{H}$ NMR data of the title compounds are given in Table $\mathbf{1}$ and $\mathbf{2}$ respectively.

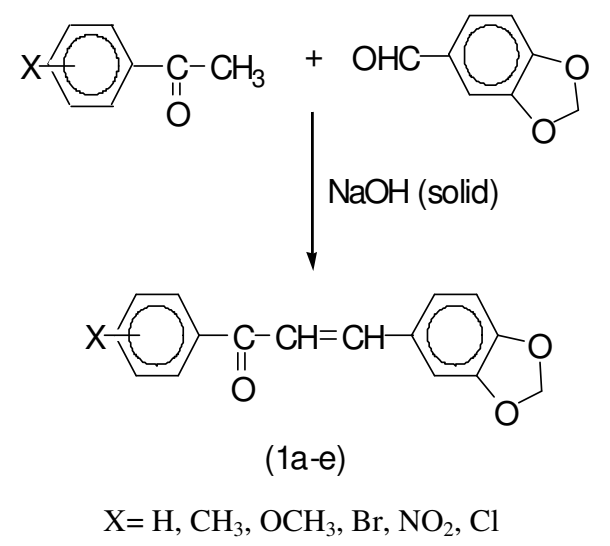

Figure-1

\section{Antibacterial activity}

The compounds were screened for antibacterial activity by cup-plate method at a concentration of $50 \mu$ $\mathrm{ml}^{-1}$ against gram-positive and gram-negative bacteria viz. Staphylococcus aureus, Escherichia coli, Streptococcus viridiaus and $K$. salmonilla using their dimethylformamide solution. The activity was compared with chloromycetin. The result (Table 3) showed that most of the chalcones possess moderate to good activity (zone of inhibition, $10-15 \mathrm{~mm}$ ). Some of the compounds containing chloro / bromo substituents were active while other possessed moderate or feeble activity against the bacteria. 
Table-1. Elemental analysis data of title compounds

\begin{tabular}{|c|c|c|c|c|c|c|}
\hline \multirow[t]{2}{*}{ Compd } & \multirow[t]{2}{*}{ M.F. } & \multirow[t]{2}{*}{ M.Wt } & \multicolumn{3}{|c|}{$\begin{array}{c}\text { Elemental Analysis } \\
\text { Calculated. and (Found) }\end{array}$} & \multirow[t]{2}{*}{ M.P. $\left({ }^{\circ} \mathrm{c}\right)$} \\
\hline & & & $\mathrm{C} \%$ & $\mathrm{H} \%$ & $\mathrm{~N} \%$ & \\
\hline $1 \mathrm{a}$ & $\mathrm{C}_{16} \mathrm{O}_{3} \mathrm{H}_{12}$ & 252 & $\begin{array}{l}76.19 \\
(76.12)\end{array}$ & $\begin{array}{l}4.76 \\
(4.60)\end{array}$ & ----- & 107 \\
\hline $1 b$ & $\mathrm{C}_{17} \mathrm{O}_{3} \mathrm{H}_{14}$ & 266 & $\begin{array}{l}76.91 \\
(76.85)\end{array}$ & $\begin{array}{l}5.26 \\
(4.23)\end{array}$ & ----- & 33 \\
\hline $1 c$ & $\mathrm{C}_{17} \mathrm{O}_{4} \mathrm{H}_{14}$ & 282 & $\begin{array}{l}72.34 \\
(72.35)\end{array}$ & $\begin{array}{l}4.96 \\
(4.90)\end{array}$ & ----- & 127 \\
\hline $1 d$ & $\mathrm{C}_{16} \mathrm{O}_{3} \mathrm{H}_{11} \mathrm{Br}$ & 331 & $\begin{array}{l}58.06 \\
(57.93)\end{array}$ & $\begin{array}{l}3.32 \\
(3.33)\end{array}$ & ----- & 134 \\
\hline $1 \mathrm{e}$ & $\mathrm{C}_{16} \mathrm{O}_{5} \mathrm{H}_{11} \mathrm{~N}$ & 297 & $\begin{array}{c}64.64 \\
(64.58)\end{array}$ & $\begin{array}{l}3.70 \\
(3.68)\end{array}$ & $\begin{array}{l}4.71 \\
(4.67)\end{array}$ & 207 \\
\hline $1 \mathrm{f}$ & $\mathrm{C}_{16} \mathrm{O}_{3} \mathrm{H}_{11} \mathrm{Cl}$ & 286.5 & $\begin{array}{l}67.02 \\
(67.01)\end{array}$ & $\begin{array}{l}3.83 \\
(3.77)\end{array}$ & ----- & 28 \\
\hline
\end{tabular}

Table-2. 1H NMR Data of Title Compounds (in $\delta, \mathrm{ppm}$ )

\begin{tabular}{|c|c|c|c|c|}
\hline Compd. & Ar-X & $\begin{array}{c}-\mathrm{C}-\mathrm{CH}=\mathrm{CH} \\
\|_{\mathrm{O}}(\alpha \mathrm{CH}) \\
1 \mathrm{H},(\mathrm{d})\end{array}$ & $\begin{array}{c}-\mathrm{C}-\mathrm{CH}=\mathrm{CH} \\
\|_{\mathrm{O}}(\beta \mathrm{CH}) \\
1 \mathrm{H},(\mathrm{d})\end{array}$ & $\begin{array}{c}\mathrm{OCH}_{2} \mathrm{O} \\
2 \mathrm{H},(\mathrm{s})\end{array}$ \\
\hline $1 \mathrm{a}$ & $\begin{array}{l}6.92-8.1, \\
\text { complex }\end{array}$ & 7.82 & 8.02 & 6.00 \\
\hline $1 b$ & $\begin{array}{c}6.72-7.89 \\
\text { complex }\end{array}$ & 7.81 & 8.04 & 5.98 \\
\hline $1 \mathrm{c}$ & $\begin{array}{c}\text { 6.912-8.22, } \\
\text { complex }\end{array}$ & 7.77 & 8.03 & 6.00 \\
\hline $1 d$ & $\begin{array}{c}6.77-8.23 \\
\text { complex }\end{array}$ & 7.84 & 8.01 & 6.00 \\
\hline $1 \mathrm{e}$ & $\begin{array}{l}\text { 6.34-7.9, } \\
\text { complex }\end{array}$ & 7.83 & 8.02 & 6.01 \\
\hline $1 \mathrm{f}$ & $\begin{array}{c}\text { 6.88-6.99, } \\
\text { complex }\end{array}$ & 7.82 & 8.03 & 6.00 \\
\hline
\end{tabular}


Table-3 Zone of inhibition of compounds 1a-1f

\begin{tabular}{|c|c|c|c|c|}
\hline S.No. & S. aure-us & E. coli. & S. viridi-aus & K. salm-onella \\
\hline $1 \mathrm{a}$ & ++ & +++ & ++ & ++ \\
\hline $1 b$ & ++ & ++ & +++ & ++ \\
\hline $1 \mathrm{c}$ & ++ & ++ & ++ & +++ \\
\hline $1 d$ & +++ & +++ & ++++ & +++ \\
\hline $1 \mathrm{e}$ & ++ & ++ & +++ & ++ \\
\hline 1f & +++ & ++++ & +++ & ++++ \\
\hline Chloromycetine & +++ & ++++ & +++ & ---- \\
\hline
\end{tabular}

\section{Conclusion}

Solvent free synthesis of chalcones was a novel method for synthesis of chalcones. The chalcones were obtained in high yield and high purity. The result indicates a correlation between the success of solvent free synthesis and melting point of the chalcones. Chalcone with relatively high melting point were obtained in high yields of these, the chalcones 1a-1f were tested for their antibacterial activity. The result showes that chalcones, containing chloro/bromo substituents were active while other possessed moderate activity against bacterias.

\section{Acknowledgement}

Authors are thankful to Head, Department of Chemistry, University of Rajasthan, Jaipur for providing laboratory facilities. Authors are also thankful to Central Drug Research Institute, Lucknow for providing spectral data. One of us Rajendra Kumar Saini is thankful to the CSIR, New Delhi for the award of Junior Research Fellowship.

\section{References}

1. Frolich S, Schubert C, Bienzle U and Siems K, Journal of Antimicrobial chemotherapy, 2005

2. Parekh A K and Desai K K, E-Journal of chemistry, 2005, 2

3. Lunarcdi F, Guzela M, Rodrigues A T, Correa R, Mangrich I E, Steindel M, Grisard E C, Assreuy J, Calixto J and Santos A R S, Antimicrobial agents and chemotherapy, 2003, 47, 1459 Makika H, Tanaka T, Fujitsuka

4. H, Tatematsu N, Satoh K and Mori H, Cancer Res., 1996, 56, 4904

5. Min B, Ahn B and Bae K, Arch. Pharm.,1996, 19, 543

6. Williams C A, Hautts J R S, Harborne J B, Greeham J and Eagler J, Phytochemistry, 1995, 38, 267

7. Mahmood N, Piacente S, Burke A, Khan A and Pizza C, Antiviral chem. chemother., 1997, 8, 70

8. Palleros D R, Journal of Chemical Education, 2004, 81, 1345

9. Seeley H W and Van Denmark P J, Microbes in action: A laboratory manual of microbiology, 1975, 55

10. Collins C H, "Microbiological Method" 1967 Karanagh F, Analytical microbiology, 1963, 125

11. Karanagh F, Analytical microbiology, 1963, 125. 


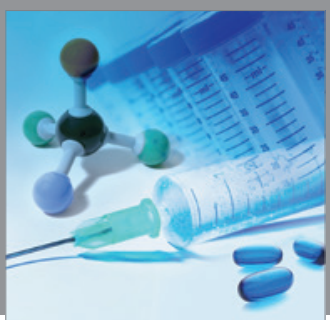

International Journal of

Medicinal Chemistry

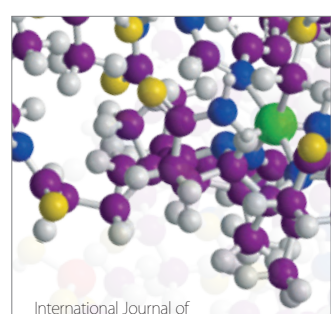

Carbohydrate Chemistry

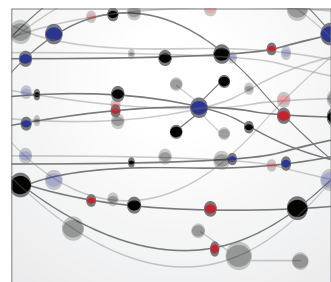

The Scientific World Journal
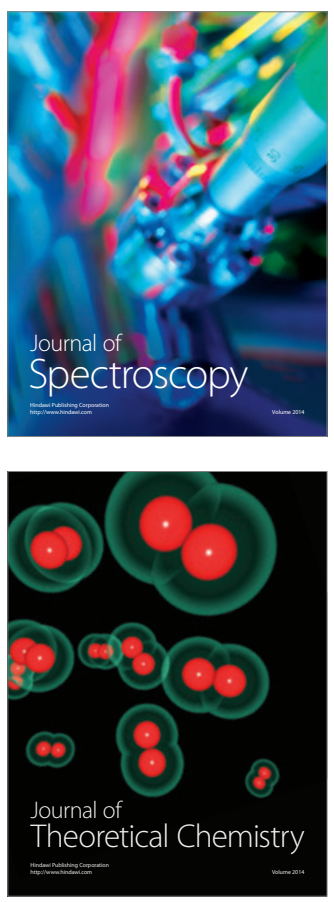
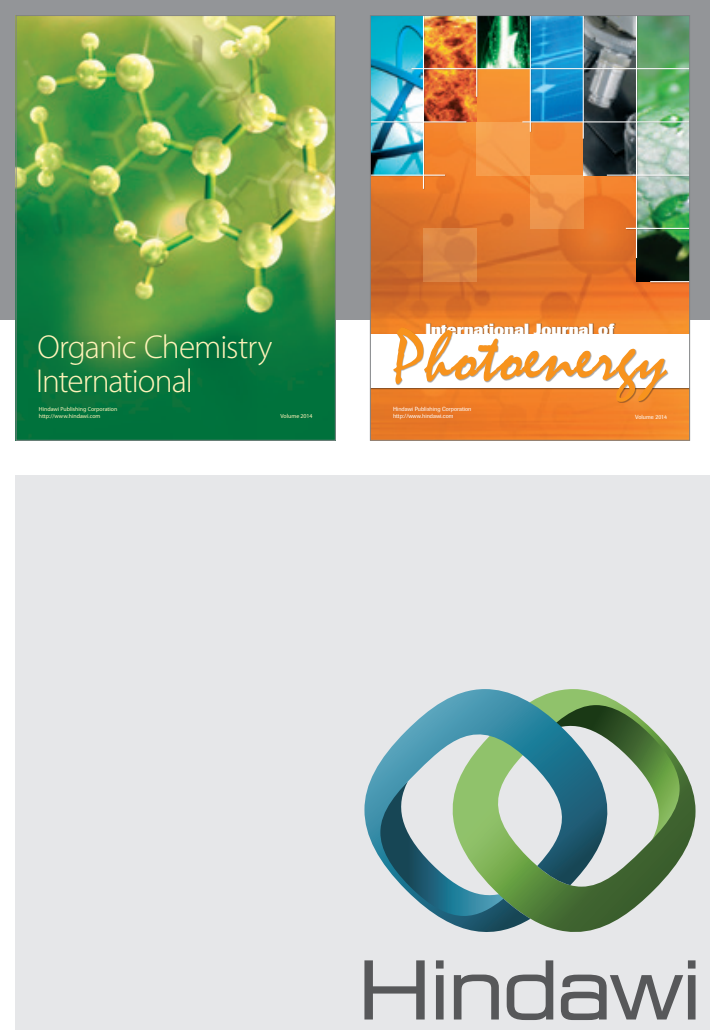

Submit your manuscripts at

http://www.hindawi.com
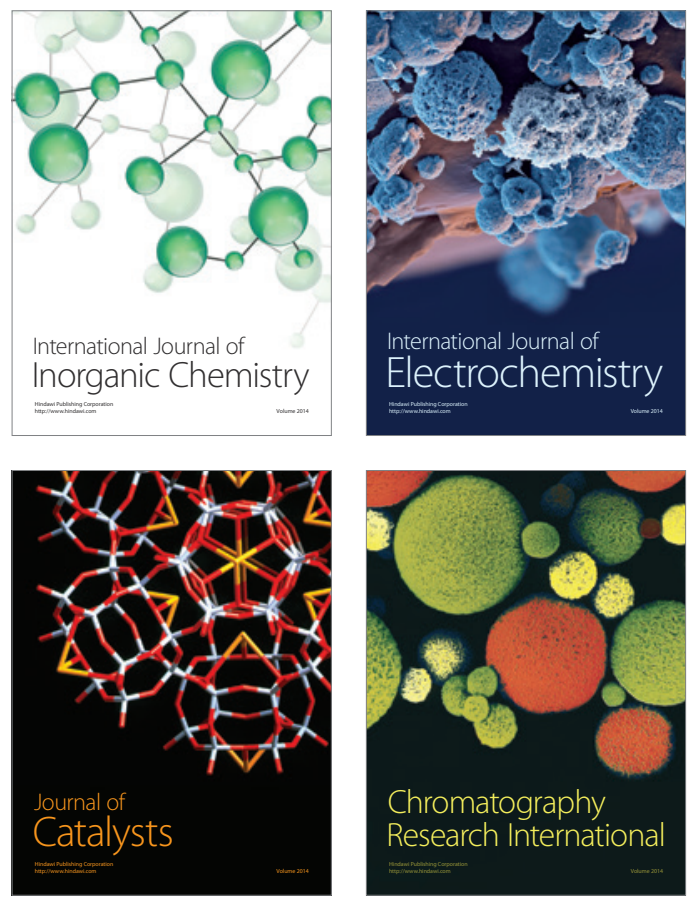
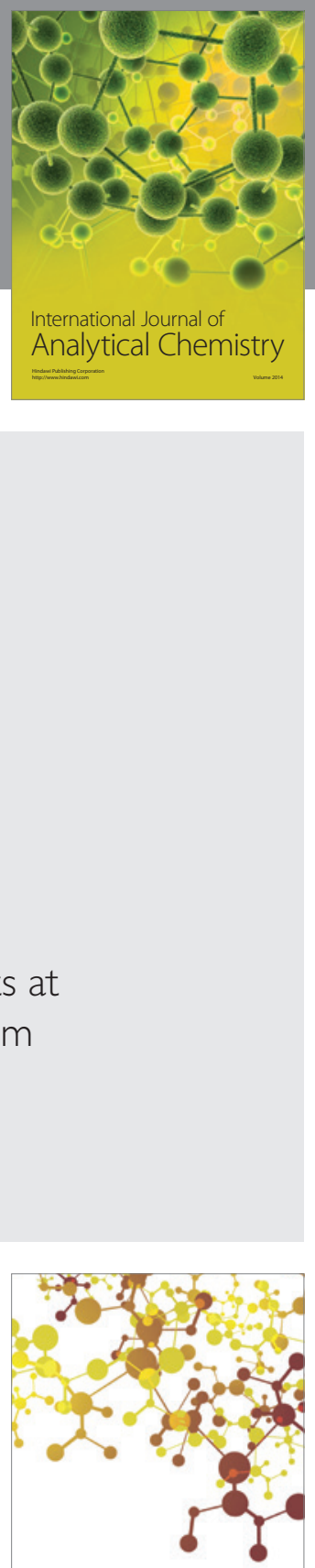

Journal of

Applied Chemistry
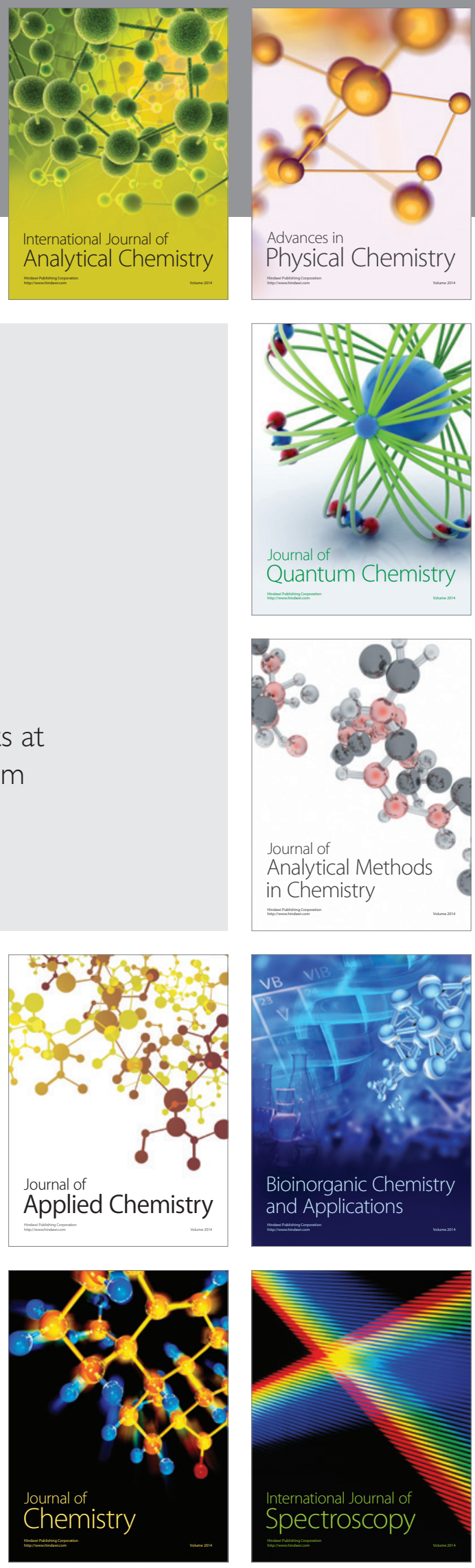